\title{
Alien plant invasions in Mediterranean habitats: an assessment for Sicily
}

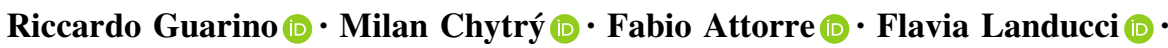 \\ Corrado Marcenò (D)
}

Received: 9 November 2020/Accepted: 1 May 2021/Published online: 11 May 2021

(C) The Author(s) 2021, corrected publication 2021

\begin{abstract}
Levels of plant invasions in different habitat types were assessed in several regional studies, but few of them were from the Mediterranean. Here we compare the levels of vascular plant invasion across habitats and plant communities of Sicily. We used a large dataset of plant species presences/absences in vegetation plots to analyze the invasion patterns across habitats considering biogeography, life form and phenology of alien plants. Vegetation plots were classified based on the EUNIS classification of European habitats. The invasiveness of each species was expressed in terms of its absolute and percentage frequency. Representation of different life forms and phenological patterns was compared between alien and native species. The fidelity of alien species to
\end{abstract}

Supplementary information The online version contains supplementary material available at (https://doi.org/10.1007/ s10530-021-02561-0).

R. Guarino $(\bowtie)$

Department of Biological, Chemical and Pharmaceutical

Sciences and Technologies, University of Palermo,

Palermo, Italy

e-mail: riccardo.guarino@unipa.it

M. Chytrý · F. Landucci · C. Marcenò

Department of Botany and Zoology, Faculty of Science,

Masaryk University, Brno, Czech Republic

F. Attorre

Department of Environmental Biology, Sapienza

University of Rome, Rome, Italy individual habitats was calculated using the phi coefficient. Our analysis shows that annual and woody species are the most represented life forms in the alien flora of Sicily and that alien species tend to have a longer flowering period than the native species. The investigated habitats differed strongly in their level of invasion by alien species, ranging from 0 to $15.6 \%$ of aliens of all species recorded. Most of the habitats were colonized by very few alien species or completely lacked them, except for sandy coasts, naturallydisturbed riverbeds, and synanthropic habitats. It must be noted, however, that the number of alien species occurring in a given habitat does not relate to the severity of the impact of invasion in that habitat. Some habitats are invaded by few (or single) species, which attain a high cover, transforming the whole ecosystem. The habitat-based approach proved to be suitable for evaluating the habitat specificity and frequency of alien species at a regional scale, improving the capacity for risk assessment in different ecological contexts.

Keywords Alien species - Biogeographical status · Flowering season · Life form · EUNIS · European vegetation archive

\section{Introduction}

Some authors have considered Mediterranean ecosystems less prone to invasion than temperate ecosystems 
as a result of the long history of interactions between the environment and humans (Di Castri 1989; Quézel et al. 1990) and summer-drought stress, which prevents the establishment of non-adapted plants (Garcia-Serrano et al. 2009). This is consistent with recent syntheses that show generally lower numbers of alien species in the Mediterranean than in temperate Europe, based on national inventories of alien floras (Lambdon et al. 2008b), Atlas Florae Europaeae grid maps (Ronk et al. 2017) or standardized plot sampling of corresponding habitats in the Mediterranean and temperate cities (Kalusová et al. 2019). However, recent studies suggest that disturbance (Dimitrakopoulos et al. 2017), human population density (Malavasi et al. 2014), habitat fragmentation (Tomaselli et al. 2012), climate change (Gritti et al. 2005), global trade (Hulme 2004), and ornamental horticulture (Pretto et al. 2012) may lead to an accelerating trend of biological invasions also in the Mediterranean region (Sanz-Elorza 2006; Celesti-Grapow et al. 2010; Celesti-Grapow and Ricotta 2021), mainly by plant species arriving from climatically similar regions of the world (Cao Pinna et al. 2021).

Mediterranean islands also seem to be less invaded than areas of continental Europe, as indicated by qualitative observations of their flora (Dal Cin D'Agata et al. 2009; Podda et al. 2010; Puddu et al. 2016). However, islands tend to be more prone to invasions than mainland regions (Lonsdale 1999), and this pattern was also observed in the Mediterranean (Gimeno et al. 2006; Celesti-Grapow et al. 2016). The reasons include a higher probability of the occurrence of unsaturated communities, a lower competitive ability of native species (Hulme 2004) and more intense human pressure, notably in summer along the coast, in lowlands and riparian habitats (Hulme et al. 2008). Also, the exposure of Mediterranean islands to biological invasions may have accelerated in recent years as it happened elsewhere. For instance, Camarda et al. (2016) report on the naturalization of 72 new alien plant species never observed before in Sardinia. The distance from the mainland, size and shape of the Mediterranean islands can influence their vulnerability to alien plant invasion (Domina and Mazzola 2011). Still, some studies (Vilà et al. 2010, 2011) suggest that biological invasions in Mediterranean insular ecosystems are no exception to the general rule that levels of invasion are context-dependent and habitat-specific (Traveset et al. 2008).
The term "habitat" originates from a speciesspecific concept (Kirk et al., 2018), but it is frequently used to designate an integral unit comprising ecological functions and species assemblages (Morrison and Mathewson 2015), as it happens in the EUNIS habitat classification adopted in the European nature conservation policies (Rodwell et al. 2018). In this sense, the invasiveness of an alien species is determined not only by its habitat preferences but also by context-specific processes and interactions between biotic communities and their invaders (Lambrinos 2002; Evangelista et al. 2008; Crosti et al. 2016).

Regional studies comparing the levels of plant invasion across Mediterranean habitats and plant communities are uncommon, most of them performed on the Iberian Peninsula (Vilà et al. 2007; Chytrý et al. 2008; González-Moreno et al. 2014). Therefore, we extend this approach eastwards to test whether the patterns documented previously have a more general validity across the Mediterranean Basin.

We focus on Sicily, the largest Mediterranean island. Due to its long-lasting human history and central location in the Mediterranean Basin, Sicily represents an ideal study area to explore alien plant invasions patterns. Although Sicily's alien vascular flora is well known (Galasso et al. 2018a, b, c), the frequency and abundance of alien species within habitat types have never been assessed.

Since vegetation cover is a primary attribute in EUNIS habitat identification (Gigante et al. 2016; Rodwell et al. 2018) and vegetation plots offer a good measure of species percentage frequencies in different habitats (Guarino et al. 2018), we used vegetation-plot data from Sicily to answer the following questions: (1) What is the affinity of alien species to specific habitats at a fine-scale? (2) Which biogeographical regions contributed the most frequent alien vascular plants to Sicily and the study habitats? (3) Which are the most frequent life forms of the alien vascular plants in Sicily and in the study habitats? (4) Are there any differences in the flowering time of alien and native plants?

\section{Methods}

Study area

Sicily and its offshore islets are recognized as one of the biodiversity hotspots in the Mediterranean Basin 
(Médail and Quézel 1999). Sharp topographic (Catalano 2004), edaphic (Fierotti 1997) and climatic (Bazan et al. 2015) contrasts make this island one of the most environmentally heterogeneous Mediterranean territories. The diversity of the Sicilian flora and vegetation is due to the complex geomorphology of the island (Carbone et al. 2018) and its palaeogeographic history, making Sicily an excellent example of the full range of common Mediterranean vegetation types (Guarino and Pasta 2017).

Its central location made Sicily a major pathway of human migration and cultural, economic and ethnic crossroads. Although palaeontological and palaeogeographic data do not exclude the possibility of a Middle Pleistocene peopling (Sineo et al. 2015), the human presence in Sicily has been unequivocally continuous since 14,000 years ago (Mannino et al. 2012). During the long history of human habitation, plant assemblages have been shaped by human activity (Tinner et al. 2016). Many alien vascular plants were introduced, although the time and pathways of these introductions remain uncertain in most cases (Mazzola and Domina 2010). At present, Sicily has 4.97 million inhabitants, with a population density of 197 people/ $\mathrm{km}^{2}$. According to the second edition of the Flora of Italy (Pignatti et al. 2017-2019), the Sicilian vascular flora consists of 3012 species, 237 of which are alien species steadily naturalized on the island and 219 are casual aliens. About eighty new alien species have been recorded in Sicily in the last two decades (Galasso et al. 2018a, b). Although some species are represented in Sicily by different subspecies, varieties and forms, only species were considered in the present study.

\section{Datasets}

The vegetation plots from Sicily stored in the European Vegetation Archive (EVA; Chytrý et al. 2016) were used as source data for species occurrences and frequencies. In June 2020, data were retrieved from the following databases (database codes follow the Global Index of Vegetation-plot Databases; www. givd.info): Mediterranean Ammophiletea Database (EU-00-016; Marcenò and Jiménez-Alfaro 2017), CircumMed Pine Forest Database (EU-00-026; Bonari et al. 2019), European Weed Vegetation Database (EU-00-028; Küzmič et al. 2020), High Mediterranean Mountains Database (EU-00-029),
Vegetation Plot Database - Sapienza University of Rome (EU-IT-011; Agrillo et al. 2017), Iberian and Macaronesian Vegetation Information System (SIVIM, EU-00-004; Font et al. 2012) and VegItaly (EU-IT-001; Landucci et al. 2012).

Vegetation plots were classified using the classification expert system for EUNIS habitats (EUNIS-ESy version 2020-06-08; Chytrý et al. 2020). Habitat types within groups A (marine, in our case coastal saltmarshes), C (aquatic) and $\mathrm{H}$ (sparsely vegetated) were classified to the types accepted in the European Red List of Habitats (Janssen et al. 2016) because these groups of habitats were not yet subjected to the revision of the EUNIS system. Unclassified plots and those assigned to multiple habitats were discarded. Only habitats represented by at least 34 plots across the whole dataset were retained for data analysis. In some cases, similar habitats not reaching the minimum number of plots were merged. This happened in the case of the habitats $\mathrm{C} 1+\mathrm{C} 2, \mathrm{~N} 1 \mathrm{~B}+\mathrm{N} 1 \mathrm{G}, \mathrm{S} 6+\mathrm{S} 72$, S93+T14, T17+18 (see Online Resource 1 for the habitat codes).

The number of plots differed among individual regions within Sicily and habitats. This imbalance can bias the estimates of frequencies and relative alien species richness (Wagner et al. 2017). While we were unable to address the uneven number of plots per habitat, we tried to reduce the bias due to the uneven geographical distribution of the vegetation plots by dataset resampling. The group of plots belonging to each habitat was resampled geographically, retaining a maximum of five plots per habitat in each quadrat of a geographical grid of 2.0 longitudinal and 1.5 latitudinal minutes (approx. $3 \mathrm{~km} \times 2.8 \mathrm{~km}$ in Sicily). The resampling procedure was not applied to the habitats containing less than 50 plots across the whole island.

Traits

Biogeographical status, life forms and months of flowering were retrieved from the electronic supplements of the Flora of Italy (Pignatti et al. 2017-2019). The origin and the status in Sicily of many archaeophytes (i.e. species presumably introduced to Italy before $1500 \mathrm{AD}$ ), particularly those related to wheat cultivation, is debated (Brullo and Guarino 2007). Therefore, we considered as alien species only the neophytes (i.e. species presumably introduced to Italy after $1500 \mathrm{AD}$ ), classified as such by Galasso, Banfi 
and Bandini Mazzanti in Galasso et al. (2018a, b, c). Archaeophytes were considered as native, with the only exception of those whose intentional introduction in Sicily is historically documented, as in the case of Arundo donax, Avena sativa, Citrus limon, C. sinensis, Rhus coriaria and Triticum turgidum.

Concerning the biogeographical status, we lumped into the "Mediterranean" all species recorded in the Flora of Italy as Pan-Mediterranean, Centro-Mediterranean, N-, NE-, NW-, E-, W-, SE-, SW- and S-Mediterranean; into the "Wide-Mediterranean" the species recorded as Eury-Mediterranean, Mediterranean-Saharian, Mediterranean-Macaronesian, Mediterranean-Turanian and Mediterranean-Pontic; into the "Subtropical" the species recorded as Saharo-Sindic, Pantropical and Palaeotropical. All the other biogeographical status were considered individually.

Only the following six life forms were considered: "Tree" (phanerophytes); "Shrub" (nano-phanerophytes and woody climbers); "Dwarf" (chamaephytes); "Herb" (hemicryptophytes and geophytes); "Hydrophyte" (helophytes and hydrophytes); "Annual" (therophytes). Some taxa were associated with more than one life-form. The complete list of alien species recorded in the dataset is reported in Online Resource 2.

Data analysis

The invasiveness of a given species was expressed as its absolute percentage frequency in the resampled dataset. The biogeographical status and the life forms were converted into dummy variables. We used the nonparametric Wilcoxon statistical test to compare the percentages of life-forms and phenology between alien and native species pools.

Following Catford et al. (2012), we quantified the level of invasion as alien species richness and relative alien species richness. We defined these measures separately for the whole habitat and for vegetation plots belonging to the habitat. As individual habitats were represented by different numbers of plots, we calculated rarefaction with the "rarefy" function included in the vegan package 2.5-7 in R (Oksanen et al. 2020) and took estimated species numbers corresponding to 34 plots. We used four measures of the level of invasion: (1) alien species richness per habitat (absolute number of alien species recorded across 34 plots belonging to the habitat), (2) relative alien species richness per habitat (number of alien species as a proportion of the number of all species recorded across 34 plots belonging to the habitat), (3) mean alien species richness per plot (absolute number of alien species recorded in a plot averaged across all the plots belonging to the habitat) and (4) mean relative alien species richness per plot number of alien species as a proportion of all species recorded in a plot averaged across all the plots belonging to the habitat). For each habitat, life forms and biogeographical status were used as descriptors of the alien species pools.

Finally, the fidelity of alien species to a given habitat was determined by measuring the concentration of species occurrences in the vegetation plots assigned to that habitat, using the phi coefficient of association (Tichý and Chytrý 2006). Species with values of $p h i \geq 0.3$ were reported as diagnostic of a given habitat in Online Resource 1. In the calculations, we assumed an equal number of plots per habitat. We disregarded those alien species whose concentration in the group was not significant at $p<0.01$, based on Fisher's exact test (Tichý and Chytrý 2006).

\section{Results}

\section{Alien flora}

In total, 6366 vegetation plots were retrieved from EVA. After classification and resampling, the dataset comprised 3655 plots, 1601 species (corresponding to $53.1 \%$ of the whole Sicilian vascular flora) and 75,969 species occurrence records. There were 70 alien species recorded in the dataset. Considering that $15.1 \%$ of the whole Sicilian flora are alien species (Pignatti et al. 2017-2019), the proportion of alien species in our dataset was significantly lower, corresponding to $4.3 \%$ of the species recorded (Fig. 1a). The relative frequency of alien species across plots in the resampled dataset was $1.3 \%$ (Fig. 1b).

Oxalis pes-caprae was by far the commonest and most ubiquitous alien species in the dataset, with 302 occurrences in 13 different habitats (Table 1; Online Resource (2), followed by Xanthium orientale and Erigeron bonariensis. 


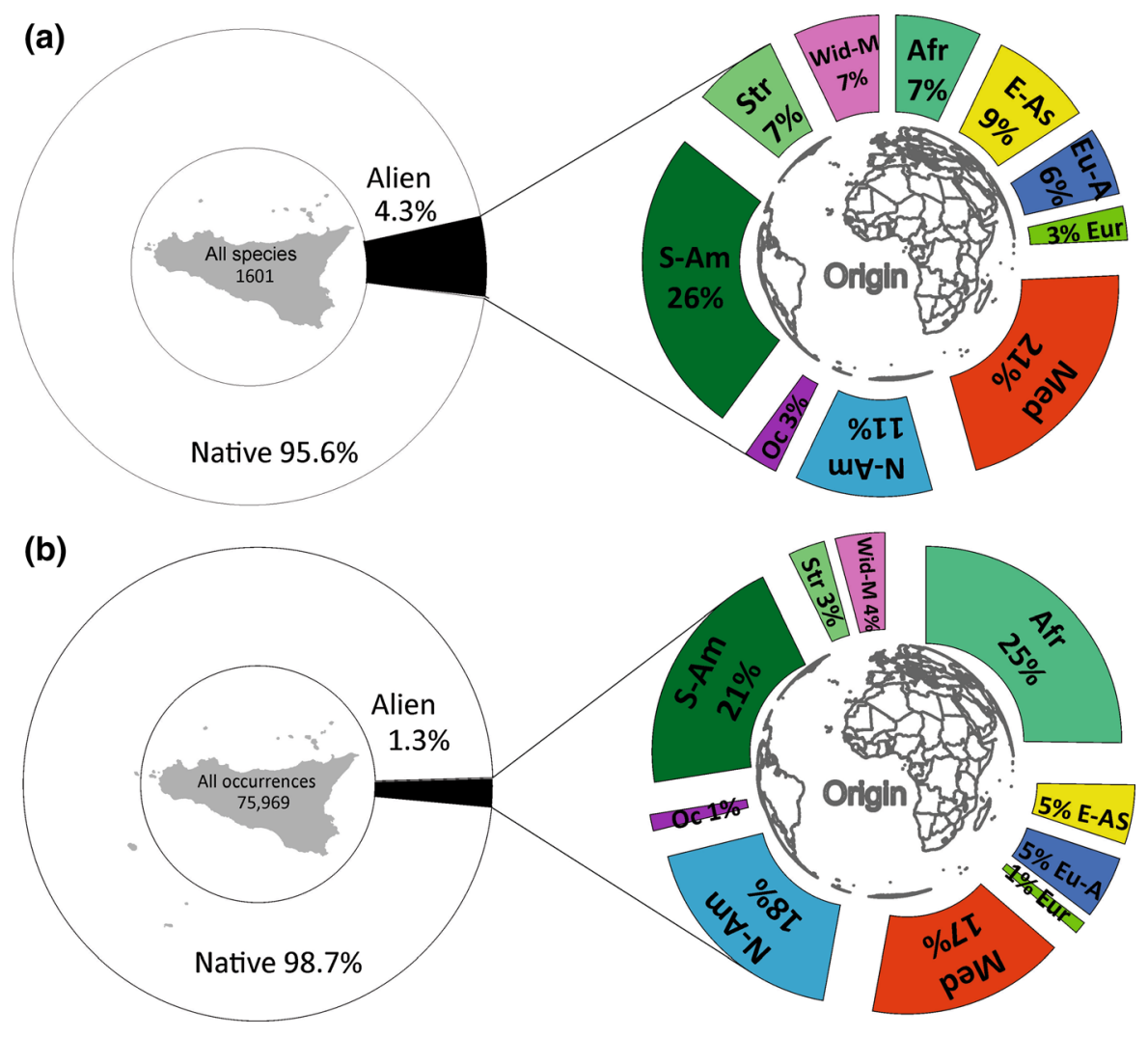

Fig. 1 a Percentage of alien species in the species pool and b relative frequency of alien species across plots in the resampled dataset, classified by their origin (standard error of the mean $<3 \%$ ). Afr = African, E-As = East-Asian, Eu-A =

\section{Origin}

Altogether, Mediterranean and wide-Mediterranean aliens were the most well-represented, accounting for 20 species and $21 \%$ of all occurrences (Fig. 1). However, the number of strictly Mediterranean aliens (15 species) was lower than that of the South American ones (18 species) and, if the relative frequencies of species across plots were considered, the most represented were African (25\%), South American (21\%), North American (18\%) and Mediterranean $(15 \%)$.

Life forms

In our dataset, 35 alien species were annuals, accounting for $50 \%$ of all alien species in the dataset (Online Resource 2). Compared to the life-forms of the native species pool (Fig. 2a), annuals, trees, shrubs,
Eurasian, $\quad$ Eur $=$ European,$\quad$ Med $=$ Mediterranean,$\quad \mathrm{N}-\mathrm{Am}=$ North-American, Oc = Oceanian, S-Am = South-American, Str $=$ Subtropical, Wid-M = Wide-Mediterranean

and dwarf shrubs were significantly over-represented and herbs significantly under-represented in the alien species pool. When the relative frequencies of species across plots were considered, alien annual and tree species were significantly more represented than the corresponding life forms of native species, whereas dwarf shrubs and herbs were significantly less represented (Fig. 2b).

The proportion of life forms in the alien pool differed (Fig. 3): South America and North America contributed mostly annual species, while most of the tree species came from Europe, East Asia and Oceania.

\section{Phenology}

Alien plant species had different patterns of flowering phenology than native species. The average curve of native species flowering time displays a more 
Table 1 The alien species with absolute frequency $\geq 10$ in the resampled dataset. Species are ordered by their occurrence frequency within the dataset, which is expressed both in the absolute number of occurrences (absolute frequency) and as a percentage of all plots in the dataset (percentage frequency)

\begin{tabular}{|c|c|c|c|c|c|}
\hline Species & Origin & Life form & $\begin{array}{l}\text { Absolute } \\
\text { frequency }\end{array}$ & $\begin{array}{l}\text { Percentage } \\
\text { frequency }\end{array}$ & $\begin{array}{l}\text { No. of EUNIS } \\
\text { habitats (tot.) }\end{array}$ \\
\hline Oxalis pes-caprae & African & Herb & 224 & 6.1 & 13 \\
\hline Xanthium orientale & North American & Annual & 97 & 2.7 & 6 \\
\hline Erigeron bonariensis & South American & Annual & 62 & 1.7 & 4 \\
\hline Lycium intricatum & Mediterranean & Shrub & 51 & 1.4 & 7 \\
\hline Symphyotrichum squamatum & South American & Annual & 40 & 1.1 & 8 \\
\hline Rhus coriaria & Mediterranean & Shrub & 31 & 0.8 & 5 \\
\hline Opuntia ficus-indica & North American & Shrub & 30 & 0.8 & 5 \\
\hline Citrus sinensis & East Asian & Tree & 23 & 0.6 & 3 \\
\hline Erigeron sumatrensis & South American & Annual & 22 & 0.6 & 4 \\
\hline Veronica persica & Eurasian & Annual & 21 & 0.6 & 3 \\
\hline Vicia faba & Mediterranean & Annual & 19 & 0.5 & 2 \\
\hline Amaranthus retroflexus & North American & Annual & 19 & 0.5 & 4 \\
\hline Galinsoga parviflora & South American & Annual & 18 & 0.5 & 3 \\
\hline Asparagus officinalis & Wide-Mediterranean & Herb & 17 & 0.5 & 2 \\
\hline Erigeron canadensis & North American & Annual & 16 & 0.4 & 5 \\
\hline Arundo donax & Eurasian & Shrub, Herb & 15 & 0.4 & 7 \\
\hline Citrus limon & East Asian & Tree & 15 & 0.4 & 2 \\
\hline Dactyloctenium aegyptium & Subtropical & Annual & 14 & 0.4 & 3 \\
\hline Sisymbrium orientale & Wide-Mediterranean & Annual & 14 & 0.4 & 1 \\
\hline Amaranthus deflexus & South American & Annual & 14 & 0.4 & 2 \\
\hline Acacia saligna & Oceanian & Shrub, Tree & 11 & 0.3 & 4 \\
\hline Cichorium pumilum & Mediterranean & Annual & 10 & 0.3 & 3 \\
\hline Megathyrsus bivonianus & Mediterranean & Herb & 10 & 0.3 & 1 \\
\hline Cenchrus setaceus & Subtropical & Herb & 10 & 0.3 & 1 \\
\hline
\end{tabular}

The number of EUNIS habitats in which the species was recorded is reported in the last column; for the whole list, see Online Resource 2

pronounced and earlier peak than the curve of alien species (Fig. 4). The flowering time of alien species is more prolonged than that of native species, with considerable prevalence in July and August.

\section{Aliens in habitats}

The investigated habitats differed strongly in their level of invasion by alien species, both of Mediterranean and non-Mediterranean origin (Fig. 5). The number of alien species ranged from 0 to 20 , representing up to $16.7 \%$ of the total number of species recorded in each habitat. Similarly, the mean number of alien species per plot scored up to $17.2 \%$ of the plot species list. The man-made habitats (habitats V1-V39) were the richest in alien species, with an average percentage frequency of $5.7 \%$. However, this figure ranged from $0.6 \%$ in the case of the dry perennial anthropogenic herbaceous vegetation (V38) to $16.7 \%$ in the case of the commensal annual vegetation of crops (V37). The vegetation of coastal saltmarshes (A25d), sandy coasts (N14-N1G), perennial dry grasslands (R1E) and riparian thickets (S93+T14) was quite prone to colonization by alien species.

In contrast, some habitats were alien-free, such as Mediterranean temporary ponds (C16b), standing and running waters $(\mathrm{C} 1+\mathrm{C} 2)$, helophyte beds (Q5), volcanic fields (H61), rocky grasslands (R14), 

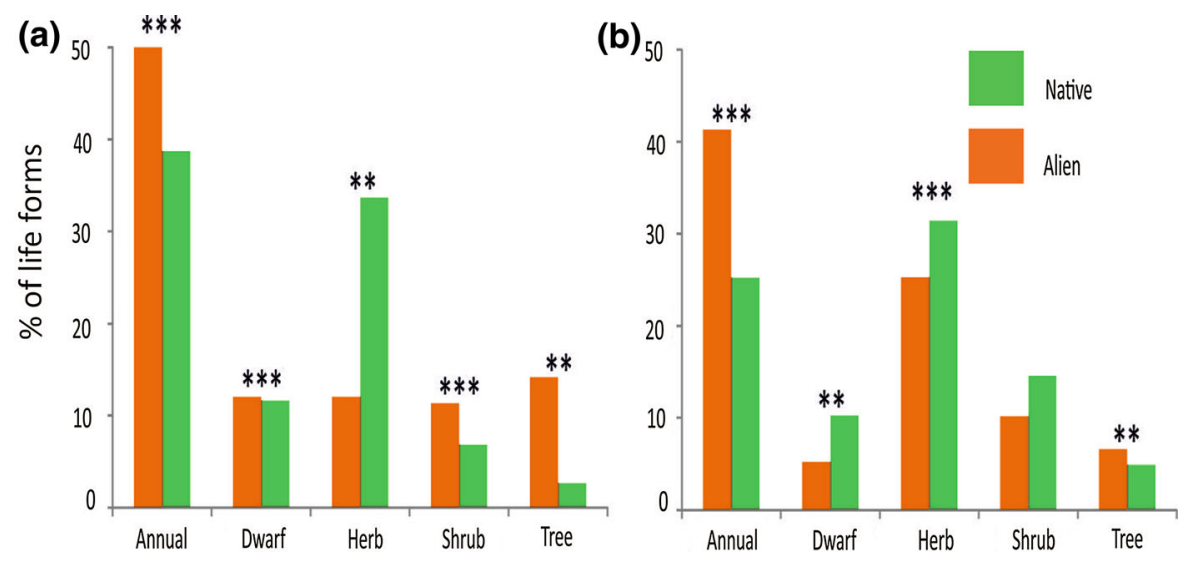

Fig. 2 a Percentage of life forms in alien and native species pools and $\mathbf{b}$ their relative frequency across plots in the resampled dataset. Asterisks indicate significant differences (Wilcoxon test, ${ }^{*} p \leq 0.01$, $* * * \leq 0.001$ ). (standard error of the mean $<1.2 \%$ )

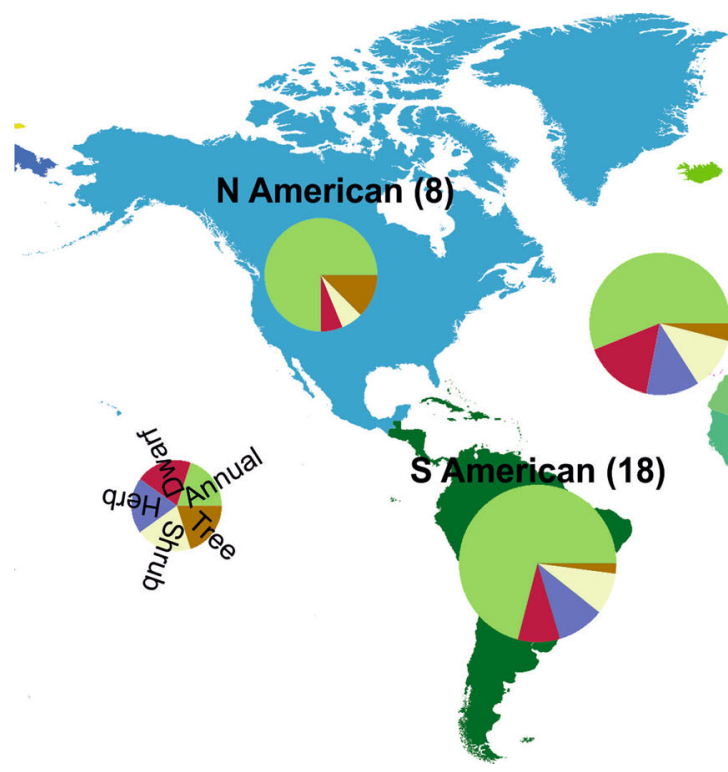

Fig. 3 Origin of alien plants in the Sicilian vegetation. The numbers of species coming from each individual region are reported in brackets. Pie size is related to the number of species contributed by each region. Pie sectors indicate the percentage

rangelands (R1D), nutrient-poor annual dry grasslands (R1R), mountain grasslands (R4), hedgehog-heaths (S74), beech forests (T17+T18), poplar and birch forests (T1D), black pine forests (T37) and Mediterranean thermophilous deciduous forests (T1A). Also, the vegetation of coastal cliffs (N32), annual communities of shallow soils (R1F), thermomediterranean arid scrub (S54), garrigue and phrygana (S6 + S72) and lowland pine forests (T3A) were almost totally free from alien species.

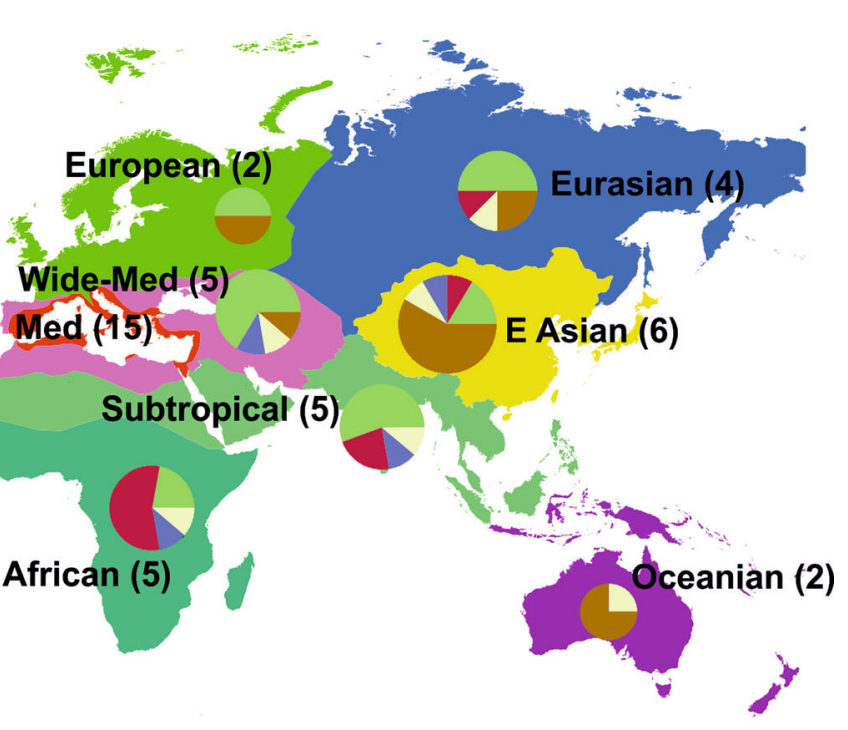

frequency of the life forms of alien species from a given biogeographic region in the dataset (note that some species are represented by more than one life form)

\section{Origin}

The alien species with a Mediterranean origin were significantly $(p<0.05)$ underrepresented in manmade habitats (V1-V39), riparian thickets $(\mathrm{S} 93+\mathrm{T} 14)$, herbaceous vegetation of coastal dunes (N12-N16) and saltmarshes (A25d). In contrast, they were significantly overrepresented $(p \leq 0.01)$ in the Mediterranean perennial dry grasslands (R1E), coastal cliffs (N32) and coastal dune thickets (N1B+N1G). 
Fig. 4 Flowering phenology of alien and native species pools. Asterisks indicate significant differences (Wilcoxon test, $* * p \leq .01$; $* * * p \leq .001)$
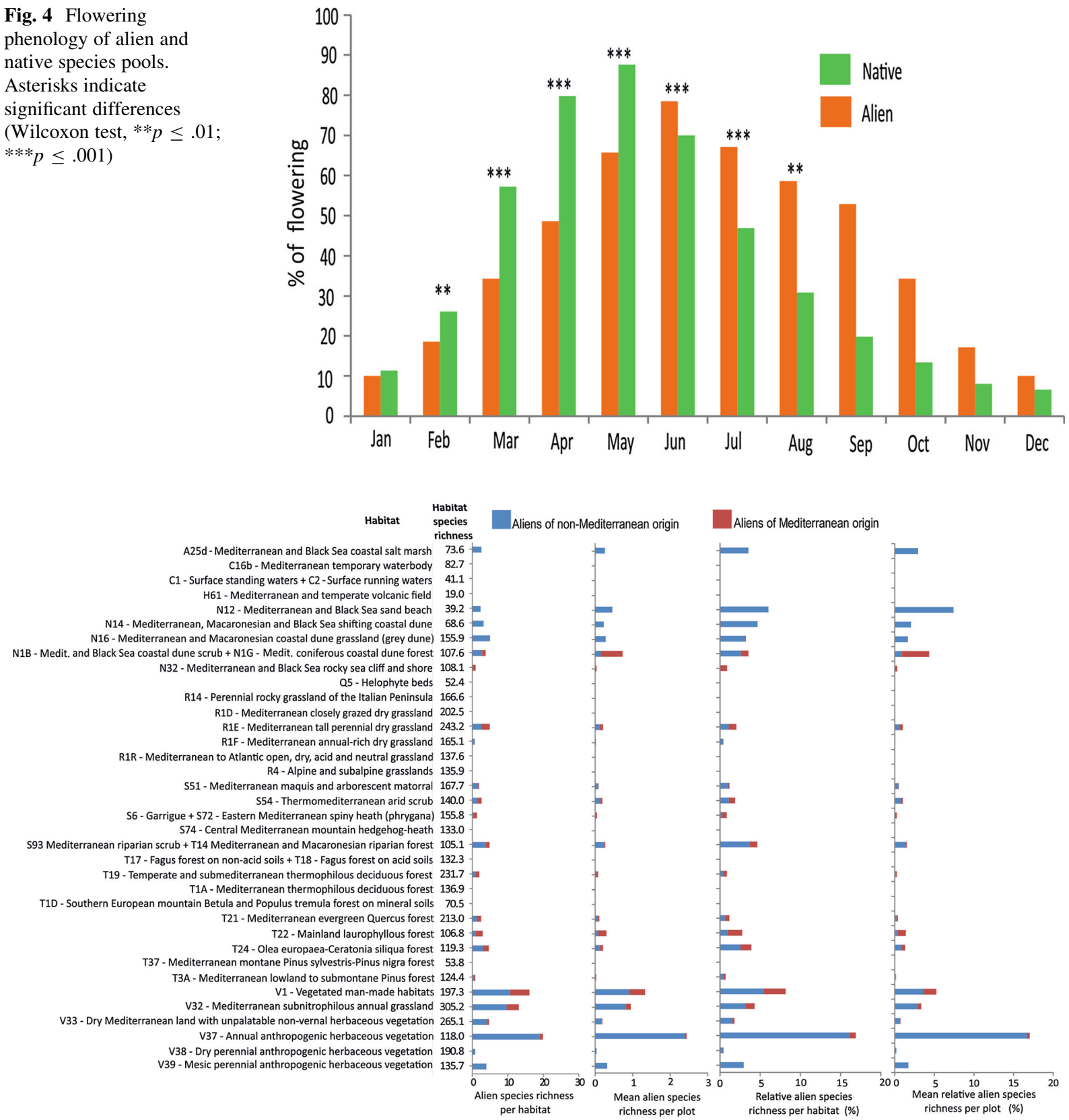

Fig. 5 Alien species richness per habitat type calculated by rarefaction for 34 plots and four different measure of the level of invasion (alien species richness per habitat, mean alien species

The South American species were represented in 11 different habitats, but they were significantly $(p<0.01)$ prevalent only in man-made habitats (V1-V37), with 15 species recorded, 12 of which were exclusive. richness per plot, relative alien species richness per habitat and mean relative alien species richness per plot)

The pattern of the North American species is comparable to that of the South American ones because they were recorded in 13 habitats. However, only three species were strongly related to man-made habitats (V1-V37). The rest of the species were related 
to sandy coasts (particularly N12 and N1B) and Mediterranean arid scrub (S54).

Despite accounting for only five species, the African species were represented in 12 different habitats, with a strong affinity to coastal sand dunes (N14 and N16) and man-made habitats (V1 and V32).

The European species were the least well-represented in the alien species pool ( 2 species and $0.9 \%$ of all occurrences) and mostly related to Quercus pubescens woods (T19). The Eurasian species (4 species) were mainly related to riparian thickets (S93+T14).

The Oceanian species (2 species) were strongly related to coastal grey dunes (N16, N1B). The Subtropical species (5 species) were most related to the beach driftline (N12) and perennial dry grasslands (R1E).

\section{Life forms}

The proportion of life forms in the alien species pool differed among habitat types (Fig. 6): annuals were most related to man-made habitats (V1-V37) and coastal sandy vegetation $(\mathrm{N} 12, \mathrm{~N} 14)$; trees to riparian thickets (S93 + T14); shrubs to coastal dune scrub and forests $(\mathrm{N} 1 \mathrm{~B}+\mathrm{N} 1 \mathrm{G})$ and Olea-Ceratonia forests (T24); herbs to perennial dry grasslands (R1E), laurophyllous forests (T22) and man-made habitats (V1, V32); dwarf shrubs to coastal dunes (N14, N16), perennial dry grasslands (R1E) and evergreen shrublands (S51, S54).

\section{Discussion}

Our results show that the distribution and frequency of alien species vary across Sicilian habitat types and are not correlated with the native species pools (Fig. 5). Rejmánek (1989) suggested that plant communities in mesic environments seem to be more prone to biological invasions than those in xeric environments. However, in contrast with this 'mesic hypothesis', the percentage frequency of alien species in the natural habitats of Sicily did not show significant differences between the habitats exposed to a prolonged and intense summer drought and those where microclimatic and edaphic conditions buffer the summer drought stress. Absence or infrequent occurrence of

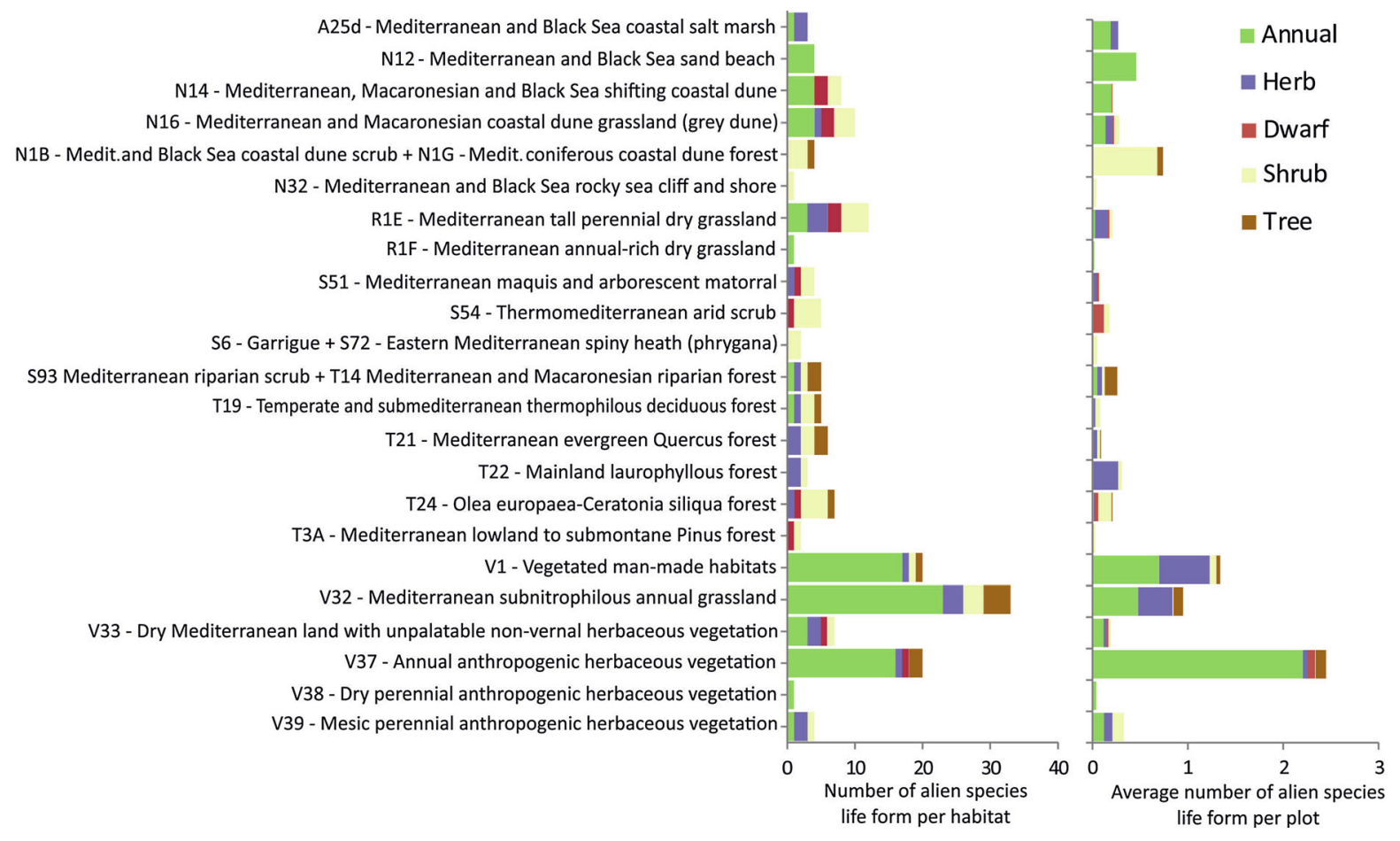

Fig. 6 Life forms of alien species per habitat type. The absolute number of aliens in the species pool, the percentage of aliens in the species pool and the mean number of aliens per plot are shown (only the habitats with at least one alien species are included) 
alien species (occurrence frequency $<2 \%$; Fig. 5) were found not only in dry habitats with nutrient-poor soils but also in mesic and very wet habitats. Similarly, the scarcity of alien species pertained not only to the typical Mediterranean evergreen forests but also to mesophilous deciduous forests and shrublands of Sicily. It must be noted, however, that the number of alien species occurring in a given habitat does not relate to the severity of the invasion in that habitat. Some habitats are invaded by few (or single) species, which attain a high cover, transforming the whole ecosystem.

Not surprisingly, highly conservative and stable habitats with constantly low levels of nutrient availability, such as coastal cliffs (N32) and rocky grasslands (R14), were characterized by the absence or low proportions of alien species (compare Cao Pinna et al. 2021), although some of these can be highly invasive, e.g. Opuntia spp. and Cenchrus setaceus. More unexpected is the observation that low proportions of alien species were also recorded in habitats that in temperate ecosystems are more prone to plant invasions, such as the thermophilous deciduous forests (T19, T1A) and even in disturbed habitats, such as the closely grazed dry grasslands (R1D) and the dry-mesic perennial anthropogenic vegetation (V38-V39). There are different possible explanations of these unexpected patterns that are partially different from what was observed in the corresponding habitats of the temperate zone (Chytrý et al. 2008). In the case of the thermophilous deciduous forests (Guarino et al. 2015) and beech forests (Brullo et al. 1999), Sicily represented a refuge area during the coldest phases of the Pleistocene (Guarino and Pasta 2018). At present, the persistence of plant communities typical of temperate or submediterranean ecosystems in isolated areas on the Sicilian mountains could make the arrival and establishment of alien species more difficult.

In the case of rangelands and perennial anthropogenic vegetation, a possible explanation is that having lumped the archaeophytes with native species in our dataset, the long-lasting occurrence of archaeophytes in centuries-old cultural landscapes became undetectable. It could be that archaeophytes saturated the empty niches created by disturbance, thus leaving little space for neophytes in these ancient man-made habitats. Moreover, the long-lasting pastoral activities led to nutrient depletion and soil impoverishment, which may hinder the alien species establishment in the Mediterranean rangelands (Ambarl1 et al. 2018; Guarino et al. 2020). Additional evidence that low nutrient content can reduce the incidence of invasive plants is provided by intentional nitrogen impoverishment carried out by restoration practitioners in grassland systems of temperate Europe (Török et al. 2014). Conversely, nutrient addition (Burke and Grime 1996) and fluctuating nutrient availability (Davis et al. 2000) can facilitate the alien plant invasion in (semi-)natural grasslands.

As far as coastal dunes are concerned, although the number of aliens in the regional species pool is substantial, their frequency in vegetation plots from the Mediterranean Region tends to be lower than along the Atlantic and Black Sea coasts (Campos et al. 2004; Giulio et al. 2020). In accordance with previous studies (Acosta et al. 2006), our results confirm that the most frequent alien species on coastal sands are: (1) fast-growing annuals with prolific seed sets, such as Dactyloctenium aegyptium and Xanthium orientale, which mainly occur on beach driftlines (N12), and (2) clonal perennial succulent species, such as Carpobrotus edulis and C. acinaciformis, mostly related to sand dunes (N14 and N16). In coastal dune scrub (N1B), the proportion of woody species, such as Acacia saligna and Eucalyptus camaldulensis, frequently also planted for dune fixation, increases as well.

In contrast to coastal sandy habitats, Mediterranean saltmarshes (A2.5d) could be less prone to alien plant invasion than those on the other European coasts due to the higher mean salinity of the Mediterranean Sea and sharply contrasting salt concentration between dry and wet seasons, which requires specific morphological and physiological adaptations (Rogel et al. 2000; Pennings et al. 2005). Similarly, the trophic and thermic seasonal fluctuations of the Mediterranean (temporary) inland waterbodies $(\mathrm{C} 1.6 \mathrm{~b}, \mathrm{C} 1+\mathrm{C} 2)$ could be the reason for the minor incidence of alien species compared to temperate Europe, even though this might not apply to artificial waterbodies (Naselli Flores and Marrone 2019).

As expected, the highest proportion of alien vascular plants was detected in periodically disturbed habitats with intermittent increases in nutrient availability (Davis et al. 2000; Chytrý et al. 2008; Viciani et al. 2020). This is particularly the case of the anthropogenic annual vegetation (V1-V37), which was by far the richest both in the number and occurrences of alien species, with the maximum 
values in the weed vegetation of irrigated summer crops (V37).

\section{Origin}

Because of the strong environmental filtering by the Mediterranean summer drought, highly successful species in the alien species pool of Sicily did not include those originating from Eurasian or European temperate regions. Also, invasions in plant communities with seasonally oscillating water availability can be dependent on different water relations and resource-use dynamics of invasive vs native species in response to water deficits (Caplan and Yeakley 2010; Funk 2013). The alien species with a Mediterranean origin were not particularly invasive in the studied habitats, as their morpho-physiological adaptations and resource-use efficiency have evolved in environmental conditions similar to those of native species (Galán Díaz et al. 2021). Instead, the subtropical region of the Old World provided several successful species, most of them highly specialized, being widespread in the Sicilian beach driftlines and gravelly riverbeds (Dactyloctenium aegyptium) and perennial dry grasslands (Boerhavia repens and Cenchrus setaceus). In particular, the alien Cenchrus setaceus can replace the native Hyparrhenia hirta in the dominance of perennial grasslands at stony sites near the coast (D'Amico and Gianguzzi 2006; Pasta et al. 2010).

The recurrence of African species in many different habitats is due to Oxalis pes-caprae, which was the most frequent alien in our dataset. The affinity of the African species to coastal dunes is due to Carpobrotus acinaciformis, C. edulis and Solanum linneanum. The original habitat of these species are coastal sands and rocky grasslands of the Cape Region (Goldblatt and Manning 2000), and they colonized sites with ecological conditions similar to those of their ancestral niche all over the Mediterranean-climate regions in the world (Santoro et al. 2011).

South America gave an important contribution to the Sicilian weeds because Amaranthus deflexus, A. muricatus, A. viridis, Datura stramonium, Erigeron bonariensis, E. sumatrensis, and Galinsoga parviflora are some of the most common and typical species in the weed vegetation of hoed crops, with optimum in the late summer-fall season, on sandy or loamy soils (Brullo et al. 2007). However, the present study revealed also the affinity of Symphyotrichum squamatum and Paspalum dilatatum to coastal saltmarshes of Sicily.

North American also contributed to the Sicilian weed flora, including Amaranthus blitoides, A. retroflexus and Erigeron canadensis. In contrast, Xanthium orientale became very common at coastal sites, particularly on beach driftlines and in the proximity of river mouths (riparian vegetation was its secondmost preferential habitat in Sicily, after beach driftlines). However, the most significant North American species in the alien flora of Sicily is Opuntia ficusindica, which became one of the most common and typical elements on the warm and dry slopes and in rocky habitats of the Sicilian landscapes, both inland and near the coast (Lo Verde and La Mantia 2011).

Oceania provided only two species to the studied alien species pool: Acacia saligna and Eucalyptus camaldulensis. Both have been favoured by deliberate plantations on coastal grey dunes since the first half of the twentieth century, threatening many autochthonous woody species typical of coastal grey dunes, such as Juniperus macrocarpa, Ephedra fragilis, E. distachya and Retama raetam subsp. gussonei (Minissale and Sciandrello 2013; Sciandrello et al. 2015).

\section{Life forms}

Annuals were largely prevailing in the alien species pool of Sicily because they can adapt very well to the combined effect of seasonal drought and disturbance related to multiple land-use patterns (Goldblatt 1978; Guarino 2006). The ubiquity of annual alien species is also related to the large extent of agricultural areas in Sicily (Brullo and Guarino 2007).

Trees were also significantly over-represented in the alien species pool, both in terms of pool percentage and species frequency across plots. This is the result of extensive tree plantations in coastal sites (particularly with Acacia saligna and Eucalyptus camaldulensis), but also of reforestation for the consolidation of unstable slopes (particularly with Ailanthus altissima, Eucalyptus camaldulensis, Pinus canariensis, P. radiata and Robinia pseudoacacia) and of partly abandoned cultivation (in the case of Citrus spp., Crataegus azarolus, Juglans regia, Malus domestica, Prunus domestica, P. dulcis and Pyrus communis). The over-representation of trees, in terms of relative frequency and species richness, compared to the life 
forms of the other alien species, was also reported by Wagner et al. (2017) in the European woodlands.

Phenology

Differences in the flowering phenology between alien and native species can be influenced by climatic conditions and photoperiod in the native distribution range (Godoy et al. 2009a, b), pollination strategy (Fontaine et al. 2006), different responses to disturbances (e.g. drought, cold, fire, see Rathcke and Lacey 1985) and biotic interactions with co-occurring plant species (Ollerton and Lack 1992; Elzinga et al. 2007). We detected different flowering phenology patterns between the groups of alien and native species. Flowering at a different time, i.e. avoiding competition for pollinators with co-occurring native species, could represent an advantage for alien species (Lambdon et al. 2008a; Sargent and Ackerly 2008). Some of the late-flowering alien species in the dataset (e.g. Echinochloa colona and Setaria italica) are related to irrigated summer crops (Lake and Leishman 2004; Lloret et al. 2005), or to the post-harvest weed vegetation of hoed crops, with an optimum in the late summer-fall season (e.g. Amaranthus spp., Datura stramonium and Galinsoga parviflora). Also, tropical bunchgrasses (Cenchrus setaceus and Megathyrsus bivonianus) invading dry grasslands and disturbed areas exhibit a later flowering than natives (Godoy et al. 2009a). Additionally, some annual species can have two generations per year in Sicily (e.g. Erigeron spp. and Symphyotrichum squamatum), one in early spring and one after the rain that marks the end of summer drought. Even if some of the recorded alien perennial species may take advantage from early (e.g. Calendula officinalis and Oxalis pes-caprae) or late (e.g. Artemisia spp., Boerhavia repens and Ricinus communis) flowering, the majority of them exhibits a long flowering season (Carpobrotus spp., Lycium intricatum, Nicotiana glauca and Solanum linneanum) in Sicily.

Previous studies have shown that alien species, particularly the invasive ones, generally display early flowering or long blooming periods (Goodwin et al. 1999; Lloret et al. 2005; Pyšek et al. 2009). However, our results reveal that there are many aliens blooming later than most of the native species, confirming previous observations from the Mediterranean Region
(Godoy et al. 2009a, b). The relatively mild winters in the Mediterranean offer more opportunities for fruit and seed development of late flowering alien species than the climates at more northern latitudes (Roche et al. 1997), even though longer and late flowering is also contributing to alien plant invasion success in central Europe (Küster et al. 2008).

\section{Caveats}

The vegetation plot data processed in this paper were sampled between 1955 and 2015, which does not allow to detect ongoing invasion processes. For instance, the recently observed trend towards naturalization and invasive behaviour by Eucalyptus camaldulensis in the pebbly riverbeds of Sicily (Badalamenti et al. 2018) remained undetected in our dataset.

Understanding the transition from non-invasive naturalized to invasive stage of the plant invasion process is important, particularly for those species that recently established in a new habitat. The presence/ absence data, as used in our study, accurately portray the adaptability of a given species to different habitats and its relative frequency but they are less suitable for assessing the invasiveness of individual alien species. For example, Cenchrus setaceus is highly invasive in the ecological niche occupied by Hyparrhenia hirta (González-Rodríguez et al. 2010; Pasta et al. 2010). Since many Hyparrhenia-dominated dry grasslands still occur where Cenchrus has not yet arrived in Sicily, our data do not reflect the extent and severity of the ongoing invasion. If the scope is to analyse the invasiveness of individual alien species, the use of cover values and diachronic studies would be recommendable.

Last but not least, the vegetation plots of our dataset were collected for the purposes of phytosociological classification (Chytrý et al. 2016). Phytosociologists tend to avoid some habitat types, such as linear features and heterogeneous habitat mosaics, especially in anthropogenic ecosystems. These habitats host noteasy-to-classify vegetation with highly stochastic species composition, but they can be preferential habitats for some plant species, especially alien. Therefore, we cannot exclude that some alien species may have been underrepresented in our dataset. 


\section{Conclusions}

Our results provide new evidence to already known general trends: (1) in small-scale vegetation plots, native and alien species richness are not related (Knops et al. 1997; Naeem et al. 2000; Hector et al. 2001; Landi et al. 2020), even if at regional scale native and alien species richness tends to be correlated (Levine and D'Antonio 1999; Levine 2000; Sax 2002; Stohlgren et al. 2003); (2) the most successful invasive species in Sicily come from climatically similar biomes (Cao Pinna et al. 2021) and tend to have an earlier, later or longer flowering period than native species (Pyšek et al. 2009; Godoy et al. 2009a, b); (3) man-made habitats harbour more alien species than any natural habitat type (Chytrý et al. 2005, 2009; Cadotte et al. 2006; Arianoutsou et al. 2010; Kalusová et al. 2017; Viciani et al. 2020); (4) naturally disturbed riverine habitats offer many temporarily vegetationfree areas to the establishment of alien species (Tickner et al. 2001; Richardson et al. 2007; Schnitzler et al. 2007; Liendo et al. 2016); (5) sandy coasts are also quite prone to colonization by alien species (Chytrý et al. 2008; Giulio et al. 2020). Except for these last three habitats, the investigated Sicilian habitats were colonized by very few alien species or completely lacking them, although lower proportions of alien species do not prevent some of these to exert the most severe environmental impacts, particularly in habitats with limited resources. Some of the alien species recorded in this study are still in a phase of rapid expansion. Three of these (Acacia saligna, Ailanthus altissima and Cenchrus setaceus) are listed in the EU Regulation 1143/2014 among the invasive species of European Union concern and possibly some more will be added in the near future, considering that many recent references (mentioned in the introduction to our study) suggest an accelerating trend of biological invasion in the Mediterranean Region.

The habitat-based approach adopted here is a suitable procedure to assess, at a regional scale, the level of invasion of different habitats (Pyšek and Chytrý 2014). Risk assessment, monitoring and management of alien plants can benefit greatly from information on the identity of receptor habitats.

Acknowledgements Custodians and contributors to the EVA databases used in this study are gratefully acknowledged.
Author contributions RG and CM conceived the idea; FA, FL provided a substantial part of the data; RG and CM prepared the data sets; $\mathrm{CM}$ processed the data and prepared the figures; $\mathrm{MC}$ supervised the analytical method; RG wrote the paper with contributions from $\mathrm{CM}$ and $\mathrm{MC}$; all authors provided critical feedback and contributed to the final version of the paper.

Funding Open access funding provided by Università degli Studi di Palermo within the CRUI-CARE Agreement. Milan Chytrý, Flavia Landucci and Corrado Marcenò were funded by the Czech Science Foundation (Project No. 19-28491X).

Availability of data and material The authors confirm that the data supporting the findings of this study are available within the article and its supplementary materials. Plot data are available upon request in the European Vegetation Archive (http://euroveg.org/eva-database).

\section{Declarations}

Conflict of interest Authors have no competing interests.

Consent for publication All authors declare that neither the article nor portions of it have been previously published elsewhere; all authors declare that the manuscript is not under consideration for publication in another journal; all authors consent to the publication of the manuscript in Biological Invasions, should the article be accepted by the Editor-in-chief upon completion of the refereeing process.

Open Access This article is licensed under a Creative Commons Attribution 4.0 International License, which permits use, sharing, adaptation, distribution and reproduction in any medium or format, as long as you give appropriate credit to the original author(s) and the source, provide a link to the Creative Commons licence, and indicate if changes were made. The images or other third party material in this article are included in the article's Creative Commons licence, unless indicated otherwise in a credit line to the material. If material is not included in the article's Creative Commons licence and your intended use is not permitted by statutory regulation or exceeds the permitted use, you will need to obtain permission directly from the copyright holder. To view a copy of this licence, visit http://creativecommons.org/licenses/by/4.0/.

\section{References}

Acosta A, Izzi CF, Stanisci A (2006) Comparison of native and alien plant traits in Mediterranean coastal dunes. Community Ecol 7:35-41

Agrillo E, Alessi N, Massimi M, Spada F, De Sanctis M, Francesconi F, Cambria VE, Attorre F (2017) Nationwide vegetation plot database-Sapienza University of Rome: State of the art, basic figures and future perspectives. Phytocoenologia 47:221-229

Ambarlı D, Vrahnakis M, Burrascano S, Naqinezhad A, Pulido Fernández M (2018) Grasslands of the Mediterranean 
Basin and the Middle East and their management. In: Squires VR, Dengler J, Feng H, Hua L (eds) Grasslands of the world: diversity, management and conservation. CRC Press, Boca Raton, FL, pp 89-112

Arianoutsou M, Delipetrou P, Celesti-Grapow L, Basnou C, Bazos I, Kokkoris Y et al (2010) Comparing naturalized alien plants and recipient habitats across an east-west gradient in the Mediterranean Basin. J Biogeogr 37:1811-1823

Badalamenti E, Cusimano D, La Mantia T, Pasta S, Romano S, Troia A, Ilardi V (2018) The ongoing naturalisation of Eucalyptus spp. in the Mediterranean Basin: new threats to native species and habitats. Aust for 81:239-249

Bazan G, Marino P, Guarino R, Domina G, Schicchi R (2015) Bioclimatology and vegetation series in Sicily: a geostatistical approach. Ann Bot Fenn 52:1-18

Bonari G, Knollová I, Vlčková P, Xystrakis F, Çoban S, Sağlam C, Didukh YP, Hennekens SM, Acosta ATR, Angiolini C, Bergmeier E, Bertacchi A, Costa JC, Fanfarillo E, Gigante D, Guarino R, Landi M, Neto CS, Pesaresi S, Rosati L, Selvi F, Sotiriou A, Stinca A, Turcato C, Tzonev R, Viciani D, Chytrý M (2019) CircumMed pine forest database: an electronic archive for Mediterranean and Submediterranean pine forest vegetation data. Phytocoenologia 49:311-318

Brullo S, Guarino R (2007) The Mediterranean weedy vegetation and its origin. Annali di Botanica 7:101-110

Brullo S, Guarino R, Minissale P, Siracusa G, Spampinato G (1999) Syntaxonomical analysis of the beech forests from Sicily. Annali di Botanica 57:121-132

Brullo S, Giusso del Galdo G, Guarino R, Minissale P, Spampinato $G$ (2007) A survey of the weedy communities of Sicily. Annali di Botanica 7:127-161

Burke MJW, Grime JP (1996) An experimental study of plant community invasibility. Ecology 77:776-790

Cadotte MW, Murray BR, Lovett-Doust J (2006) Ecological patterns and biological invasions: using regional species inventories in macroecology. Biol Invasions 8:809-821

Camarda I, Cossu TA, Carta L, Brunu A, Brundu G (2016) An updated inventory of the non-native flora of Sardinia (Italy). Plant Biosyst 150:1106-1118

Campos JA, Herrera M, Biurrun I, Loidi J (2004) The role of alien plants in the natural coastal vegetation in centralnorthern Spain. Biodivers Conserv 13:2275-2293

Cao Pinna L, Axmanová I, Chytrý M, Malavasi M, Acosta ATR, Giulio S, Attorre F, Bergmeier E, Biurrun I, Campos JA, Font X, Küzmič F, Landucci F, Marcenò C, RodríguezRojo MP, Carboni M (2021) The biogeography of alien plant invasions in the Mediterranean. J Veg Sci 32:e12980

Caplan JS, Yeakley JA (2010) Water relations advantages for invasive Rubus armeniacus over two native ruderal congeners. Plant Ecol 210:169-179

Carbone S, Di Stefano P, Monaco C, Sulli A (2018) Sicilia e isole minori. Volume 1. Società Geologica Italiana, Guide Geologiche Regionali, 390 pp.

Catalano R (2004) Geology of Sicily: an introduction. Bocconea 17:33-46

Catford JA, Vesk PA, Richardson DM, Pyšek P (2012) Quantifying levels of biological invasion: towards the objective classification of invaded and invasible ecosystems. Glob Change Biol 18:44-62
Celesti-Grapow L, Ricotta C (2021) Plant invasion as an emerging challenge for the conservation of heritage sites: the spread of ornamental trees on ancient monuments in Rome, Italy. Biol Invasions 23:1191-1206

Celesti-Grapow L, Alessandrini A, Arrigoni PV et al (2010) Non-native flora of Italy: species distribution and threats. Plant Biosyst 144:12-28

Celesti-Grapow L, Bassi L, Brundu G et al (2016) Plant invasions on small Mediterranean islands: an overview. Plant Biosyst 150:1119-1133

Chytrý M, Pyšek P, Tichý L, Knollová I, Danihelka J (2005) Invasions by alien plants in the Czech Republic: a quantitative assessment across habitats. Preslia 77:339-354

Chytrý M, Maskell LC, Pino J, Pyšek P, Vilà M, Font X, Smart SM (2008) Habitat invasions by alien plants: a quantitative comparison among Mediterranean, subcontinental and oceanic regions of Europe. J Appl Ecol 45:448-458

Chytrý M, Pyšek P, Wild J, Pino J, Maskell LC, Vilà M (2009) European map of alien plant invasions based on the quantitative assessment across habitats. Divers Distrib 15:98-107

Chytrý M, Hennekens SM, Jiménez-Alfaro B et al (2016) European vegetation archive (EVA): an integrated database of European vegetation plots. Appl Veg Sci 19:173-180

Chytrý M, Tichý L, Hennekens SM et al (2020) EUNIS Habitat classification: expert system, characteristic species combinations and distribution maps of European habitats. Appl Veg Sci 23:648-675

Crosti R, Agrillo E, Ciccarese L, Guarino R, Paris P, Testi A (2016) Assessing escapes from old stands of Short Rotation Forest plantation of Robinia pseudoacacia: a study in central Italy. iForest 9:822-828

Dal Cin DC, Skoula M, Brundu G (2009) A preliminary inventory of the alien flora of Crete (Greece). Bocconea 23:301-315

D’Amico A, Gianguzzi L (2006) Note ecologiche e distributive su poaceae di interesse fitogeografico in Sicilia. Naturalista Siciliano 30:59-74

Davis MA, Grime JP, Thompson K (2000) Fluctuating resources in plant communities: a general theory of invasibility. J Ecol 88:528-534

Di Castri F (1989) History of biological invasions with special emphasis on the Old World. In: Drake JA, Mooney HA, Di Castri F, Groves RH, Kruger FJ, Rejmánek M, Williamson M (eds) Biological invasions. A global perspective. SCOPE 37. Wiley, Chichester, pp 1-30

Dimitrakopoulos PG, Koukoulas S, Galanidis A, Delipetrou P, Gounaridis D, Touloumi K, Arianoutsou M (2017) Factors shaping alien plant species richness spatial patterns across Natura 2000 special areas of conservation of Greece. Sci Total Environ 601:461-468

Domina G, Mazzola P (2011) Considerazioni biogeografiche sulla presenza di specie aliene nella flora vascolare del Mediterraneo [Biogeographical considerations on vascular alien flora in the Mediterranean]. Biogeographia 30:269-276

Elzinga JA, Atlan A, Biere A, Gigord L, Weis AE, Bernasconi G (2007) Time after time: flowering phenology and biotic interactions. Trends Ecol Evol 22:432-439 
Evangelista PH, Kumar S, Stohlgren TJ, Jamevich CS, Crall AW, Norman JB, Barnett DT (2008) Modelling invasion for a habitat generalist and a specialist plant species. Divers Distrib 14:808-817

Fierotti G (1997) I suoli della Sicilia. Flaccovio Editore, Palermo

Font X, Pérez-García N, Biurrun I, Fernández-González F, Lence C (2012) The Iberian and macaronesian vegetation information system (SIVIM, www. sivim.info), five years of online vegetation's data publishing. Plant Sociol 49:89-95

Fontaine C, Dajoz I, Meriguet J, Loreau M (2006) Functional diversity of plant-pollinator interaction webs enhances the persistence of plant communities. PLoS Biol 4:129-135

Funk JL (2013) The physiology of invasive plants in low-resource environments. Conserv Physiol 1:026

Galán DJ, de la Riva EG, Funk JL et al (2021) Functional segregation of resource-use strategies of native and invasive plants across Mediterranean biome communities. Biol Invasions 23:253-266

Galasso G, Conti F, Peruzzi L et al (2018a) An updated checklist of the vascular flora alien to Italy. Plant Biosyst 152:556-592

Galasso G, Domina G, Adorni M et al (2018b) Notulae to the Italian alien vascular flora: 5. Ital Bot 5:45

Galasso G, Domina G, Alessandrini A et al (2018c) Notulae to the Italian alien vascular flora: 6. Ital Bot 6:65

Garcia-Serrano H, Caño L, Escarré J, Fleck I, Sans FX (2009) Physiological comparison of alien Senecio inaequidens and $S$. pterophorus and native $S$. malacitanus: implications for invasion. Flora 204:445-455

Gigante D, Attorre F, Venanzoni R et al (2016) A methodological protocol for Annex I Habitats monitoring: the contribution of vegetation science. Plant Sociol 53:77-87

Gimeno I, Vilà M, Hulme PE (2006) Are islands more susceptible to plant invasion than continents? A test using Oxalis pes-caprae in the western Mediterranean. J Biogeogr 33:1559-1565

Giulio S, Acosta ATR, Carboni M, Campos JA, Chytrý M, Loidi J, Pergl J, Pyšek P, Isermann M, Janssen JAM, Rodwell JS, Schaminée JHJ, Marcenò C (2020) Alien flora across European coastal dunes. Appl Veg Sci 23:317-327

Godoy O, Richardson DM, Valladares F, Castro-Diez P (2009a) a) Flowering phenology of invasive alien plant species compared with native species in three Mediterranean-type ecosystems. Ann Bot 103:485-494

Godoy O, Castro-Diez P, Valladares F, Costa-Tenorio M (2009b) b) Different flowering phenology of alien invasive species in Spain: evidence for the use of an empty temporal niche? Plant Biol 11:803-811

Goldblatt P (1978) Analysis of the flora of southern Africa: its characteristics, relationships and origins. Ann Mo Bot Gard 65:369-436

Goldblatt P, Manning J (2000) Cape plants: a conspectus of the Cape flora of South Africa. National Botanical Institute, Pretoria, South Africa, (Strelitzia, Vol. 9) and Missouri Botanical Garden, St Louis, Missouri, USA. 743 pp.

González-Moreno P, Diez JM, Ibáñez I, Font X, Vilà M (2014) Plant invasions are context-dependent: multiscale effects of climate, human activity and habitat. Divers Distrib 20:720-731
González-Rodríguez AM, Baruch Z, Palomo D, Cruz-Trujillo G, Soledad Jiménez M, Morales D (2010) Ecophysiology of the invader Pennisetum setaceum and three native grasses in the Canary Islands. Acta Oecologica 36:248-254

Goodwin BJ, McAllister AJ, Fahrig L (1999) Predicting invasiveness of plant species based on biological information. Conserv Biol 13:422-426

Gritti E, Smith B, Sykes MT (2006) Vulnerability of Mediterranean basin ecosystems to climate change and invasion by exotic plant species. J Biogeogr 33:145-157

Guarino R (2006) On the origin and evolution of the Mediterranean dry grasslands. Berichte der Reinhold-Tüxen Gesellschaft 18:195-206

Guarino R, Pasta S (2017) Botanical excursions in central and western Sicily. Field Guide for the 60th IAVS Symposium (Palermo, 20-24 June 2017). Palermo University Press

Guarino R, Pasta S (2018) Sicily: the island that didn't know to be an archipelago. Berichte der Reinhold Tüxen Gesellschaft 30:133-148

Guarino R, Bazan G, Paura B (2015) Downy-oak woods of Italy: phytogeographical remarks on a controversial taxonomic and ecologic issue. In: Box E, Fujiwara K (eds) Warmtemperate Deciduous Forests around the Northern Hemisphere. Geobotany Studies. Springer International Publishing, pp 139-152

Guarino R, Willner W, Pignatti S, Attorre F, Loidi J (2018) Spatio-temporal variations in the application of the BraunBlanquet approach in Europe. Phytocoenologia 48:239-250

Guarino R, Vranakis M, Rodríguez-Rojo MP, Giuga L, Pasta S (2020) Grasslands and Shrublands of the Mediterranean Region. In: Goldstein M, Della Sala D (eds) Encyclopedia of the World's Biomes, vol 2. Oxford Academic Press, Elsevier, pp 638-655

Hector A, Dobson K, Minns A, Bazeley-White E, Lawton JH (2001) Community diversity and invasion resistance: an experimental test in a grassland ecosystem and a review of comparable studies. Ecol Res 16:819-831

Hulme PE (2004) Invasions, islands and impacts A Mediterranean perspective. In: Fernandez Palacios JM, Morici C (Eds.) Island ecology. Asociación Española de Ecología Terrestre, La Laguna, pp 337-361

Hulme PE, Brundu G, Camarda I, Dalias P, Lambdon P, Lloret F, Médail F, Moragues E, Suehs CM, Traveset A, Troumbis A, Vilà M (2008) Assessing the risks to Mediterranean islands ecosystems from alien plant introductions. In: Tokarska-Guzik B, Brock JH, Brundu G, Child L, Daehler CC, Pyšek P (eds) Plant invasions: human perception, ecological impacts and management. Backhuys Publishers, Leiden, pp 39-56

Janssen JAM, Rodwell JS, García Criado M, et al (2016) Red List of European habitats: 2. Terrestrial and freshwater habitats. Brussels: European Commission

Kalusová V, Chytrý M, van Kleunen M, Mucina L, Dawson W, Essl F, Kreft H, Pergl J, Weigelt P, Winter M, Pyšek P (2017) Naturalization of European plants on other continents: the role of donor habitats. Proc Natl Acad Sci 114:13756-13761

Kalusová V, Čeplová N, Chytrý M, Danihelka J, Dřevojan P, Fajmon K, Hájek O, Kalníková V, Novák P, Řehořek V, Těšitel J, Tichý L, Wirth T, Lososová Z (2019) Similar 
responses of native and alien floras in European cities to climate. J Biogeogr 46:1406-1418

Kirk DA, Park AC, Smith AC, Howes BJ, Prouse BK, Kyssa NG, Fairhurst EN, Prior KA (2018) Our use, misuse, and abandonment of a concept: Whither habitat? Ecol Evol 8:4197-4208

Knops JMH, Tilman D, Naeem S, Howe KM (1997) Biodiversity and plant invasions in experimental grassland plots. Bull Ecol Soc Am 78:125

Küster EC, Kühn I, Bruelheide H, Klotz S (2008) Trait interactions help explain plant invasion success in the German flora: trait interactions and invasion success. J Ecol 96:860-868

Küzmič F, Šilc U, Lososová Z, Mucina L, Chytrý M, Knollová I, Hennekens SM, Berg C, Bergmeier E, Biurrun I, Fanfarillo E, Font J, Iakushenko D, Kovačević Z, Meyer S, Nagy K, Pinke G, Poranen E, Tereshenko S (2020) European weed vegetation database - a gap-focused vegetation-plot database. Phytocoenologia 50:93-100

Lake JC, Leishman MR (2004) Invasion success of exotics in natural ecosystems: the role of disturbance, plant attributes and freedom from herbivores. Biol Cons 117:215-226

Lambdon PW, Lloret F, Hulme PE (2008a) Do alien plants on Mediterranean islands tend to invade different niches from native species? Biol Invasions 10:703-716

Lambdon PW, Pyšek P, Basnou C et al (2008b) Alien flora of Europe: species diversity, temporal trends, geographical patterns and research needs. Preslia 80:101-149

Lambrinos JG (2002) The variable invasive success of Cortaderia species in a complex landscape. Ecology 83:518-529

Landi S, Tordoni E, Amici V, Bacaro G, Carboni M, Filibeck G, Scoppola A, Bagella S (2020) Contrasting patterns of native and non-native plants in a network of protected areas across spatial scales. Biodivers Conserv 29:2035-2053

Landucci F, Acosta ATR, Agrillo E et al (2012) VegItaly: the Italian collaborative project for a national vegetation database. Plant Biosystems 146:756-763

Levine JM (2000) Species diversity and biological invasions: relating local process to community pattern. Science 288:852-854

Levine JM, D'Antonio CM (1999) Elton revisited: a review of evidence linking diversity and invasibility. Oikos 87:15-26

Liendo D, García-Mijangos I, Campos JA, López-Muniain U, Biurrun I (2016) Drivers of plant invasion at broad and fine scale in short temperate streams. River Res Appl 32:1730-1739

Lloret F, Medail F, Brundu G, Camarda I, Moragues E, Rita J, Lambdon P, Hulme PE (2005) Species attributes and invasion success by alien plants on Mediterranean islands. J Ecol 93:512-520

Lo Verde G, La Mantia T (2011) The role of native flower visitors in pollinating Opuntia ficus-indica (L.) Mill., naturalized in Sicily. Acta Oecologica 37:413-417

Lonsdale WM (1999) Global patterns of plant invasions and the concept of invasibility. Ecology 80:1522-1536

Malavasi M, Santoro R, Cutini M, Acosta ATR, Carranza ML (2014) The impact of human pressure on landscape patterns and plant species richness in Mediterranean coastal dunes. Plant Biosyst 29:1541-1550
Mannino MA, Catalano G, Talamo S, Mannino G, Di Salvo R, Catalano G, Schimmenti V, Lalueza-Fox C, Messina A, Petruso D, Caramelli D, Richards MP, Sineo L (2012) Origin and diet of the prehistoric hunter-gatherers on the Mediterranean Island of Favignana Egadi Islands Sicily. PLoS ONE 7:e49802

Marcenò C, Jiménez-Alfaro B (2017) The Mediterranean Ammophiletea Database: a comprehensive dataset of coastal dune vegetation. Phytocoenologia 47:95-105

Mazzola P, Domina G (2010) Sicilia. In: Celesti-Grapow L, Pretto E, Carli E, Blasi C (eds) Flora vascolare alloctona e invasiva delle regioni d'Italia. Casa Editrice Università La Sapienza, Rome, pp 143-148

Médail F (2017) The specific vulnerability of plant biodiversity and vegetation on Mediterranean islands in the face of global change. Reg Environ Change 17:1775-1790

Médail F, Quézel P (1999) Biodiversity Hotspots in the Mediterranean Basin: setting global conservation priorities. Conserv Biol 13:1510-1513

Minissale P, Sciandrello S (2013) A relic wood of Juniperus turbinata Guss. (Cupressaceae) in Sicily: structural and ecological features, conservation perspectives. Plant Biosyst 147:145-157

Morrison ML, Mathewson HA (2015) Wildlife habitat conservation: Concepts, challenges, and solutions. John Hopkins University, Baltimore, MD

Naeem S, Knops JMH, Tilman D, Howe KM, Kennedy T, Gale S (2000) Plant diversity increases resistance to invasion in the absence of covarying extrinsic factors. Oikos 91:97-108

Naselli Flores L, Marrone F (2019) Different invasibility of permanent and temporary waterbodies in a semiarid Mediterranean Island. Inland Waters 9:411-421

Oksanen J, Blanchet FG, Friendly M, Kindt R, Legendre P, McGlinn D, Minchin PR, O'Hara RB, Simpson, GL et al (2020) Vegan: Community Ecology Package. R package version 2.5-7. http://CRAN.R-project.org/package=vegan. Accessed 20 March 2021

Ollerton J, Lack AJ (1992) Flowering phenology: an example of relaxation in natural selection? Trends Ecol Evol 7:274-276

Pasta S, Badalamenti E, La Mantia T (2010) Tempi e modi di un'invasione incontrastata: Pennisetum setaceum (Forssk.) Chiov. (Poaceae) in Sicilia. Il Naturalista Siciliano 34:63-201

Pennings SC, Grant MB, Bertness MD (2005) Plant zonation in low-latitude salt marshes: disentangling the roles of flooding, salinity and competition. J Ecol 93:159-167

Pignatti S, Guarino R, La Rosa M (2017-2019) Flora d'Italia, 2nd edition, vol 1-4. Edagricole, Edizioni Agricole di New Business Media, Bologna

Podda L, Fraga I, Arguimbau P, Mayoral García-Berlanga O, Mascia F, Bacchetta G (2010) Comparacion de la flora exotica vascular en sistemas de islas continentales: Cerdena (Italia) y Baleares (Espana). Anales Del Jardín Botánico De Madrid 67:157-176

Pretto F, Celesti-Grapow L, Carli E, Brundu G, Blasi C (2012) Determinants of non-native plant species richness and composition across small Mediterranean islands. Biol Invasions 14:2559-2572 
Puddu S, Podda L, Mayoral O, Delage A, Hugot L, Petit Y, Bacchetta G (2016) Comparative analysis of the alien vascular flora of Sardinia and Corsica. Notulae Botanicae Horti Agrobotanici Cluj-Napoca 44:337-346

Pyšek P, Chytrý M (2014) Habitat invasion research: where vegetation science and invasion ecology meet. J Veg Sci 25:1181-1187

Pyšek P, Jarošík V, Pergl J, Randall R, Chytrý M, Kühn I, Tichý L, Danihelka J, Chrtek Jun J, Sádlo J (2009) The global invasion success of Central European plants is related to distribution characteristics in their native range and species traits. Diversit Distrib 15:891-903

Rathcke B, Lacey EP (1985) Phenological patterns of terrestrial plants. Annu Rev Ecol Syst 16:179-214

Rejmánek M (1989) Invasibility of plant communities. In: Drake JA, Mooney HA, Di Castri F, Groves RH, Kruger FJ, Rejmánek M, Williamson M (eds) Biological Invasions. A Global Perspective. Wiley, Chichester, pp 369-388

Richardson DM, Holmes PM, Esler KJ, Galatowitsch SM, Stromberg JC, Kirkman SP, Pyšek P, Hobbs RJ (2007) Riparian vegetation: degradation, alien plant invasions, and restoration prospects. Divers Distrib 13:126-139

Roche CT, Thill DC, Shafii B (1997) Prediction of flowering in common crupina (Crupina vulgaris). Weed Sci 45:519-528

Rodwell JS, Evans D, Schaminée JHJ (2018) Phytosociological relationships in European Union policy-related habitat classifications. Rendiconti Lincei Scienze Fisiche e Naturali 29:237-249

Rogel JA, Ariza FA, Silla RO (2000) Soil salinity and moisture gradients and plant zonation in Mediterranean salt marshes of Southeast Spain. Wetlands 20:357-372

Ronk A, Szava-Kovats R, Zobel M, Pärtel M (2017) Observed and dark diversity of alien plant species in Europe: estimating future invasion risk. Biodivers Conserv 26:899-916

Santoro R, Jucker T, Carranza ML, Acosta ATR (2011) Assessing the effects of Carpobrotus invasion on coastal dune soils. Does the nature of the invaded habitat matter? Community Ecol 12:234-240

Sanz-Elorza M, Dana ED, Sobrino E (2006) Invasibility of an island area in NE Spain by alien plants. Acta Oecologica 29:114-122

Sargent RD, Ackerly DD (2008) Plant-pollinator interactions and the assembly of plant communities. Trends Ecol Evol 23:123-130

Sax DF (2002) Native and naturalized plant diversity are positively correlated in scrub communities of California and Chile. Divers Distrib 8:193-210

Schnitzler A, Hale BW, Alsum EM (2007) Examining native and exotic species diversity in European riparian forests. Biol Cons 138:146-156

Sciandrello S, Tomaselli G, Minissale P (2015) The role of natural vegetation in the analysis of the spatio-temporal changes of coastal dune system: a case study in Sicily. J Coast Conserv 19:199-212
Sineo L, Petruso D, Forgia V, Messina AD, D’Amore G (2015) Human peopling of Sicily during quaternary. In: Fernández LD (ed) The Quaternary period. AcademyPublish.org, Cheyenne, WY, pp 25-68

Stohlgren TJ, Barnett D, Kartesz J (2003) The rich get richer: patterns of plant invasions in the United States. Front Ecol Environ 1:11-14

Tichý L (2002) JUICE, software for vegetation classification. J Veg Sci 13:451-453

Tichý L, Chytrý M (2006) Statistical determination of diagnostic species for site groups of unequal size. J Veg Sci 17:809-818

Tickner DP, Angold PG, Gurnell AM, Mountford JO (2001) Riparian plant invasions: hydrogeomorphological control. Prog Phys Geogr 25:22-52

Tinner W, Vescovi E, van Leeuwen J, Colombaroli D, Henne PD, Kaltenrieder P, Morales-Molino C, Beffa G, Gnaegi B, van der Knaap PWO, La Mantia T, Pasta S (2016) Holocene vegetation and fire history of the mountains of Northern Sicily (Italy). Veg Hist Archeobotany 25:499-519

Tomaselli V, Tenerelli P, Sciandrello S (2012) Mapping and quantifying habitat fragmentation in small coastal areas: a case study of three protected wetlands in Apulia (Italy). Environ Monit Assess 184:693-713

Török K, Szitár K, Halassy M, Szabó R, Szili-Kovács T, Baráth N, Paschke MW (2014) Long-term outcome of nitrogen immobilization to restore endemic sand grassland in Hungary. J Appl Ecol 51:756-765

Traveset A, Brundu G, Carta L, Mprezetou I, Lambdon P, Manca M, Médail F, Moragues E, Rodríguez-Pérez J, Siamantziouras ASD, Suehs CM, Troumbis AY, Vilà M, Hulme PE (2008) Consistent performance of invasive plant species within and among islands of the Mediterranean basin. Biol Invasions 10:847-858

Viciani D, Vidali M, Gigante D et al (2020) A first checklist of the alien-dominated vegetation in Italy. Plant Sociol 57(1):29-54

Vilà M, Pino J, Font X (2007) Regional assessment of plant invasions across different habitat types. J Veg Sci 18:35-42

Vilà M, Pino J, Montero A, Font X (2010) Are island plant communities more invaded than their mainland counterparts? J Veg Sci 21:438-446

Vilà M, Espinar JL, Hejda M et al (2011) Ecological impacts of invasive alien plants: a meta-analysis of their effects on species, communities and ecosystems. Ecol Lett 14:702-708

Wagner V, Chytrý M, Jiménez-Alfaro B et al (2017) Alien plant invasion in European woodlands. Divers Distrib 23:969-981

Publisher's Note Springer Nature remains neutral with regard to jurisdictional claims in published maps and institutional affiliations. 